\title{
UPAYA PENINGKATAN IMUNITAS MASYARAKAT TERHADAP PANDEMI COVID- 19 DELTA MELALUI PEMBUATAN JAMU INSTAN
}

\author{
Sugiarto*, Arifatus Soliha, Muhammad Abdan Syakuro Fisyahri Rhamadan, \\ Abdurrohman Sholeh, Abdul Aji, Aris, Arif Gunawan, Muhammad Reza Syahrul, \\ Sahrul Eka Prasetia, Dodi Aditian Alfayit, Nurlailah, Dewi Ianah, Hidayatul Firda \\ Fakultas Pertanian, Universitas Islam Malang \\ *korespondensi email: sugiartounisma9@gmail.com
}

\begin{abstract}
ABSTRAK
Penanganan COVID 19, total kasus positif di Indonesia sebanyak 3.774.155 kasus, dari angka tersebut 3.247.715 orang dinyatakan sembuh, dan meninggal dunia 113.664 orang. Daya tahan tubuh yang rendah menjadi salah satu penyebab tingginya laju penularan covid-19. Kuatnya imunitas tubuh merupakan salah satu cara untuk menghindari infeksi virus COVID 19_Delta. Peningkatan antibody terhadap pathogen dapat dibentuk dengan mengkonsumsi dari jamu yang terbaut dari tanaman empon empon. Jamu herbal merupakan salah satu pilihan sebagai pengobatan alami untuk memperkuat imun tubuh masyarakat karena bahan baku yang mudah didapat, dan bisa dibuat sendiri. Tujuan kegiatan pengabdian masyarakat ini di harapkan dapat meningkatkan keterampilan masyarakat dengan membuat jamu instan untuk meningkatkan imun tubuh secara mandiri. Metode plaksanaan, kegiatan dilaksanakan di Desa Torongrejo, Kecamatan Junrejo, Kota Batu. Metode pengambilan sampling data menggunakan metode Participation Action Research (PAR) dan analisis data memakai likert. Parameter yang diambil adalah persepsi masyarakat mengenai obat tradisional, Respon $i$ masyarakat dalam budidaya tanaman rempah dan pemanfaatannya. Hasil kegiatan menunjukkan masyarakat respon terhadap pembuatan jamu instan, masyarakat menjadi terampil dalam mengolah rempah rempah disekitar rumah sebagai obat herbal alami. Masyarakat mengetahui tentang manfaat dan pentingnya pelestarian tanaman obat.
\end{abstract}

Kata Kunci: jamu herbal; imunitasi; covid-19

\section{PENDAHULUAN}

Pandemi Covid-19 merupakan problem dunia pada saat ini dan masih belum mereda, bahkan cenderung meningkat kasus yang berkembang di masyarakat. Perkembangan virus yang sudah mengalami mutasi gen dan membentuk varian baru. Diberbagai daerah banyak manusia yang terinfeksi virus corona varian dengan lambang Delta. Penyebaran virus varian delta telah menyebar dan menyebabkan peningkatan kasus kematian di seluruh dunia termasuk Indonesia. Indonesia termasuk negara yang sangat berpotensi untuk perkembangan pathogen virus corona. Disinyalir bahwa kasus terpapar covid Indonesia menempati urutan teratas pada level dunia. Indonesia tercatat sebanyak 3.774.155 kasus, diantaranya 3.247.715 orang dinyatakan sembuh dan meninggal dunia 113.664 orang. Wilayah dengan peningkatan kasus harian COVID-19 tertinggi di Indonesia antara lain Jawa Tengah jumlah 5.300, Jawa Timur 3.161, Jawa Barat 1.868, Bali 1.353, dan Sumatra Utara 1.314 (Firdaus, 2021). 
Tingginya jumlah kasus harian Covid-19 di berbagai wilayah pada umumnya dipicu oleh ketidakdisiplinan masyarakat di daerah dalam menjalankan protokol kesehatan. Berkembangnya virus corona 19 Delta disebabkan oleh pengetahuan dan pemahaman masyarakat terhadap siklus hidup pathogen. Siklus hidup virus corona berdasar hasil analisis medical adalah 14 hari. Perkembangan virus corona di Indonesia atau di desa juga disebabkan karena terbawa oleh carrier.

Pola hidup masyarakat di pedesaan khususnya sangat kurang peduli atau meremehkan terhadap pademi virus corona yang merupakan pathogen yang sangat berbahaya. Demikian pula pola kehidupan diperkotaan relatif masih banyak yang kurang disiplin terhadap protokol kesehatan, sehingga perkembangan di berbagai wilayah kota semakin meningkat. Hal ini terbukti pada daerah atau wilayah yang padat dengan aktivitas businees seperti pasar, super market, pabrik, tempat hiburan, warung, dan lain lainnya.

Persoalan dengan semakin rumitnya menangani pandemi ini akibat ada keterkaitan dengan permasalahan sosial, ekonomi, pendidikan dan kesehatan, sehingga menimbulkan berbagai spekulasi dari masyarakat untuk melakukan aktivitas tanpa mempedulikan keselamatan diri atau banyak yang tidak mematuhi protokol kesehatan. Hal lain juga disebabkan tingkat mobilitas masyarakat yang sangat tinggi sehingga berpeluang untuk menularkan karena bertindak sebagai carrier. Perkembangan virus corona19_delta yang sudah merebak dimana mana menimbulkan persoalan baru dimana vasilitas rumah sakit dan tenaga kesehatan menjadi tidak memadai dikarenakan tidak mampu menampung jumlah pasien yang terpapar Covid 19.

Upaya membantu pemerintah untuk menekan masyarakat agar tidak terpapar covid18_delta yaitu mendorong masyarakat agar meningkatkan daya tahan tubuh atau peningkatan imunitas tubuh. Imunitas tubuh manusia dapat dibentuk dari pola makan yang sehat dan mengandung unsur atau senyawa tertentu yang dapat meningkatkan antibody. Imunitas juga dapat diperoleh dari vaksinasi yaitu memasukkan virus corona yang telah dilemahkan potensi pathogenesitasnya. Harapannya orang yang telah di vaksin bisa mempunyai kekebalan tubuh yang baik terhadap serangan covid19_delta.

Menjaga imunitas tubuh adalah salah satu cara untuk menghindari infeksi virus Covid 19 Delta. Jamu herbal merupakan obat alami yang ada dan mudah didapat di sekitar rumah serta bermanfaat untuk memperkuat daya tahan tubuh. Jamu masih sangat popular dikalangan orang perkotaan maupun pedesaan walaupun sudah banyak obat-obat modern pada saat ini (Kusumo et al., 2020). Terlebih pada saat masa pandemi orang berusaha mendapatkan obat kimia, namun dengan keterbatasan jumlah obat kimia dan penyakit yang belum ditemukan obat spesifik untuk mengatasi virus covid maka yang terbaik adalah meningkatkan daya tahan tubuh agar tidak terinfeksi pathogen khususnya virus corona.

Pemanfaatan tumbuhan empon empon atau terkenal dengan istilah apotik hidup, merupakan alternatif yang dapat dipergunakan sebagai penangkal segala penyakit yang akan menyerang tubuh. Tanaman empon empon merupakan tanaman obat yang bisa dimanfaatkan mulai dari rimpang, umbi, akar, batang, kulit, daun, bunga, buah dan bijinya. Bagian-bagian tersebut mengandung senyawa bioaktif yang merupakan hasil metabolism yang dimanfaatkan sebagai jamu atau obat herbal untuk meningkatkan imunitas tubuh dan sebagai bumbu masak (Pramesthi et al., 2020).

Budidaya tanaman empon empon atau apotik hidup khususnya kunyit (Curcuma domestica Val. syn. Curcuma longa L.) mempunyai nilai cukup strategis baik dari sudut ekonomis maupun kesehatan masyarakat. Tanaman kunyit mempunyai kandungan senyawa minyak atsiri 4,2 - 6,2 \%, dan kadar kurkumin 9,95\% tergantung pada varietas. Tiga senyawa kurkuminoid sebagai kandungan utama dari kunyit adalah senyawa1,7-bis(4hidroksi-3-metoksifenil)-1,6 heptadiena-3,6-dion yang disebut banyak berperan dalam 
aktivitas biologis, kemudian senyawa turunannya 1-(4-hidroksi-3-metoksifenil)7(4hidroksifenil)-1,6-heptadiena-3,5-dion atau demetoksi kurkumin dan senyawa turunannya yang lain adalah 1,7-bis(4hidroksifenil)-1,6heptadiena-3,5-dion atau bisdemetoksi kurkumin. Rimpang kunyit juga mengandung berbagai macam zat fitokimia lainnya yaitu: zingiberene, curcumenol, curcumol, eugenol, tetrahydrocurcumin, triethylcurcumin, turmerin, turmerones, dan turmeronols. Senyawa ini sangat berguna untuk meningkatkan imunitas tubuh manusia.

Beberapa manfaat farmakologis kandungan kurkumin pada kunyit sudah terbukti secara ilmiah adalah sebagai : aktivitas antioksidan, antiinflamasi, antivirus, antibakteri, diabetes, radang sendi, penyakit Alzheimer, dan penyakit kronis lainnya. Rimpang kunyit juga memiliki aktivitas sebagai imunomodulator dan antivirus, berpotensi sebagai obat herbal untuk meningkatkan daya tahan tubuh dan penangkal wabah pandemi virus mematikan.

Tanaman temulawak (Curcuma zanthorrhiza Roxb) adalah tanaman rempah yang seringkali digunakan sebagai obat tradisional. Mengandung beberapa senyawa kimia yang bermanfaat untuk kesehatan manusia. Kandungan pada empu temulawak antara lain : Mengandung bahan aktif kurkuminoid, minyak atsiri, pati, protein, lemak, selulosa, dan mineral. Kurkuminoid mempunyai aroma khas, tidak toksik (tidak beracun), dan berbentuk serbuk dengan rasa sedikit pahit. Minyak atsiri pada temulawak mengandung seskuiterpen, acurcumene, 1-sikloisoprenmyrcene, zingiberene, xanthorrhizol, turunan lisabolen, epolisidbisakuron,bisakuron $A, B, C$, ketonseskuiterpen, turmeron, a-turmeron, aatlanton, germakron, monoterpen, sineol, dborneol, d-a-phellandrene,dan d-camphene (Afifah, 2005). Dilaporkan juga bahwa senyawa fenol yang terkandung didalam temulawak mampu berperan sebagai antioksidan yang dapat menghilangkan radikal bebas dan radikal peroksida yang efektif menghambat oksidasi sel penyebab penyakit kanker. Manfaat rimpang temu lawak adalah Penambah nafsu makan, antimikroba, anti-inflamasi dan antioksidan (Martino et al., 2018; Utami \& Puspaningtyas, 2013).

Tanaman kunci (Boesenbergia pandurata Roxb.) adalah tumbuhan berdaun lebar yang seringkali dimanfaatkan untuk bumbu masak dan obat. Adapun khasiat tanaman ini empu dan rimpang kunci untuk mengobati kanker, menyembuhkan sariawan, batuk kering, mencegah gigi berlubang, obat masuk angin, mengatasi panas dalam, mencegah maag, melancarkan buang air kecil, mengobati gatal-gatal pada kulit karena infeksi jamur atau alergi. Tanaman kunci mempunyai kandungan senyawa seperti : Panduratin A merupakan senyawa yang berpotensi untuk mengobati penyakit kanker. Adapun kandungan lain dari empu kunci adalah pinostrobin, boesenbergin, krachaizin, panduratin, candamonin, 5,7dimethoxyflavone, 1-8-cineole, panduratin A, flavonoid, alkaloid, minyak atseri, kamper, methyl cinnamate, dborneol,1-8 cineol, asam fenolik, saponin, vitamin B6 dan B12 (Bermawie, 2020; Dhiani et al., 2021).

Budidaya apotik hidup dapat dilakukan dimana saja terutama pemanfaatan lahan kosong disekitar rumah, bisa juga menggunakan polibag atau media buatan lainnya. Tanaman seperti kunyit, temulawak dan kunci termasuk jenis tanaman yang mudah tumbuh dan tidak memerlukan persyaratan tumbuh yang spesifik. Lahan kosong atau lahan berlereng disekitar wilayah Desa Terongrejo masih banyak yang bisa dimanfaatkan untuk budidaya tanaman apotik hidup. Budidaya pada lahan kosong juga bermanfaat untuk menjaga kelestarian hidup dan meningkatkan nilai tambah lahan yang lebih produktif.

\section{METODE}

Kegiatan pengabdian kepada mayarakat ini dilaksanakan di Desa Torongrejo, Kecamatan Jurnrejo, Kota Batu tahun, 2021. Metode pengambilan sampling data 
menggunakan pendekatan Participation Action Research (PAR). Penggalian informasi juga dilakukan dengan penyebaran kuisioner. Analisis data dari persepsi masyarakat mengenai obat tradisional, persepsi masyarakat dalam budidaya tanaman rempah dan pemanfaatannya dinyatakan dengan skor likert. Skor pernyataan diberi kategori penilaian yaitu sangat setuju=5; setuju=4; cukup setuju=3; tidak setuju=2; dan sangat tidak setuju=1. Setiap pernyataan di masing-masing kategori yang telah diberikan nilai maka akan dijumlahkan dan dikalikan dengan scale rating dari skor likert, dengan persamaan: Total Skor $=\mathrm{T} \times \mathrm{Pn}$. Keterangan: $\mathrm{T}=$ Total jumlah responden yang memilih $\mathrm{Pn}=$ Pilihan angka skor likert. Semua hasil yang didapatkan untuk setiap kategori akan dijumlahkan tiap pernyataan dan digunakan untuk menghitung persentase menggunakan rumus sebagai berikut: Rumus Indeks $=$ Total Skor $/$ Y x $100 \%$. Keterangan: Total skor $=$ Total tiap kategori yang dijumlahkan untuk setiap pernyataan, $\mathrm{Y}=$ Skor tertinggi likert $\times$ jumlah responden. Persentase yang diperoleh akan dilihat berdasarkan kriteria analisa deskriptif persentase nilai 0 - 19,99\%= Sangat tidak setuju atau kurang baik sekali; $20-39,99 \%=$ Tidak setuju atau kurang baik; 40 - 59,99\%= Cukup setuju atau netral; 60 - 79,99\%= Setuju atau baik; 80 $100 \%=$ Sangat setuju atau sangat baik (Dewi, 2019).

\section{HASIL DAN PEMBAHASAN}

Data kasus covid-19 di Desa Torongrejo per tanggal 23 Agustus terkonfirmasi sebanyak 41 kasus korban covid-19, dari angka tersebut terdapat 11 orang aktif, 27 sembuh, dan sebanyak 3 korban lainnya meninggal (Satgas Covid Torongrejo, 2021).

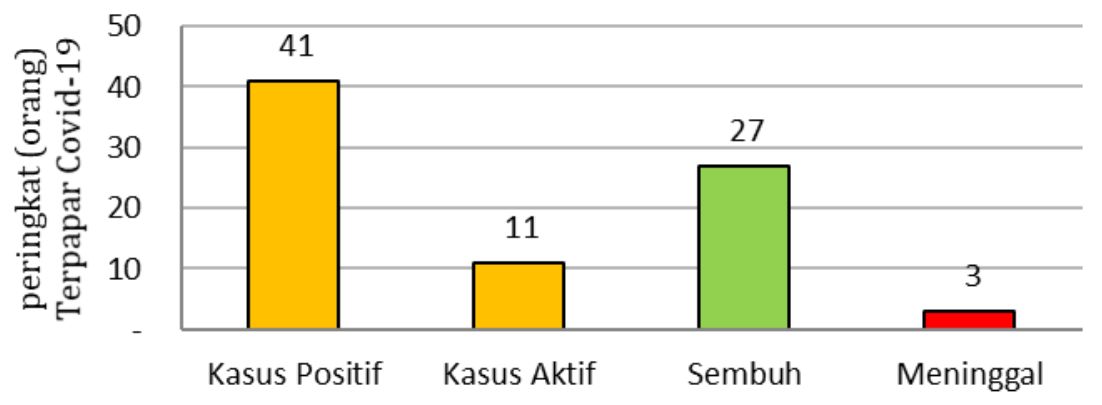

Gambar 1. Data Covid-19 Desa Torongrejo Kota Batu 2021

Berdasarkan data tersebut menunjukkan bahwa masih banyak warga Desa Torongrejo yang terdampak covid-19. Pemerintah telah memberi instruksi terkait Pemberlakuan Pembatasan Kegiatan Masyarakat dan Kota Batu sampai saat ini masih tergolong level 4. Beberapa cara untuk menurunkan korban dampak covid-19 adalah dengan mentaati protokol kesehatan dengan mentaati peraturan, menggunakan handsinitizer atau mencuci tangan dengan air yang mengalir, menggunakan masker setiap berpergian atau keluar rumah, mejaga jarak, menjaga imun tubuh dengan konsumsi makanan yang sehat dan bergizi dan mengonsumsi obat alami seperti jamu herbal.

Salah satu cara untuk menjaga imunitas tubuh selama pandemi adalah dengan mengonsumsi obat berbahan alami seperti jamu herbal. Jamu herbal merupakan jamu tradisional yang didapatkan melalui bahan-bahan alami. Bahan diambil dari bagian tanaman yaitu rimpang, daun-daunan, kulit batang, dan buah. Jamu herbal mempunyai manfaat untuk meningkatkan imunitas tubuh. Khusus untuk daya tahan tubuh agar mampu mencegah terpapar serangan pathogen virus corona 19_delta, herbal diambil dari bagian empu kunyit, empu temulawak, dan empu kunci. Manfaat tanaman kunyit memiliki kandungan zingiberene, curcumenol, curcumol, eugenol, tetrahydrocurcumin, triethylcurcumin, turmerin, turmerones, dan turmeronols yang memiliki manfaat secara ilimiah sebagai imunomodulator 
dan antivirus. Jamu herbal ini mempunyai khasiat i sebagai obat alami yaitu untuk meningkatkan imunitas tubuh dan penangkal wabah pandemi virus mematikan seperti Covid 19_delta. Temulawak memiliki kandungan kurkuminoid untuk menyembuhkan sakit kepala, maag, sakit perut, antimikroba dan mempunyai sifat antioksidan. Sedangkan kunci memiliki kandungan Senyawa pinostrobin, boesenbergin, krachaizin, panduratin, candamonin, 5,7-dimethoxyflavone, 1,8-cineole, panduratin A, flavonoid, alkaloid, methyl cinnamate, dborneol, 1-8 cineol, asam fenolik, saponin, minyak atsiri, kamper, vitamin B6 dan B12. Senyawa tersebut bermanfaat sebagai antioksidan dan meningkatkan stamina tubuh(Bermawie N et al., 2020).

Bahan tambahan lain seperti gula pasir, kayu manis, serai merah dan cengkeh untuk melengkapi senyawa yang dibutuhkan oleh tubuh dalam meningkatkan kekebalan tubuh. Adapun kandungan senyawanya antara lain: fenolik (asam galat), flavonol glukosida, komponen fenol (eugenol, asetil eugenol), dan tanin. Bunga cengkeh bermanfaat sebagai antioksidan, anti-inflamasi, antibakteri dan antivirus. Masyarakat Desa Torongrejo memahami pentingnya tanaman rempah terkait pelestarian dan maupun manfaat sebagai obat tradisional.

Tabel 1. Persepsi Masyarakat Desa Terongrejo, Junrejo, Batu, Mengenai Obat Tradisional

\begin{tabular}{lcl}
\hline \multicolumn{1}{c}{ Pernyataan } & (\%) & Interpretasi \\
\hline Tanaman rempah sangat perlu dilestarikan & 90 & Sangat Setuju \\
Produk olahan rempah (jamu) dapat meningkatkan imun tubuh & 91 & Sangat Setuju \\
Produk olahan rempah (jamu) bermanfaat bagi tubuh. & 90 & Sangat Setuju \\
Mengkonsumsi jamu tidak ada efek samping bagi tubuh. & 88 & Sangat Setuju \\
Jamu merupakan warisan leluhur atau nenek moyang. & 92 & Sangat Setuju \\
Mengkonsumsi jamu menjadi kebiasaan di lingkungan keluarga. & 89 & Sangat Setuju \\
\hline
\end{tabular}

Berdasarkan tabel 1. Masyarakat Desa Torongrejo menunjukkan sangat setuju mengenai obat tradisional yang meliputi tanaman rempah perlu dilestarikan, jamu dapat meningkatkan imun tubuh, bermanfaat bagi tubuh, tidak menimbulkan efek samping, warisan leluhur, dan konsumsi jamu menjadi kebiasaan dilingkungan keluarga. Hal ini menunjukkan bahwa masyarakat mengenal tanaman obat secara turun-menurun dari generasi ke generasi dari manfaat secara empiris maupun secara ilmiah. Namun manusia modern saat ini, tidak ingin repot dengan meracik jamu sendiri. Semua harus serba praktis, serba cepat. Pembuatan jamu instan dimaksudkan agar masyarakat bisa mewujudkan kemandirian dalam menciptakan ketahanan tubuh. Harapan lain merupakan peluang usaha sekala kecil di masa pandemi.

Pembuatan jamu tradisional diperlukan sumber bahan baku yang tersedia cukup banyak disekitar wilayah desa. Bahan baku tanaman yang dipergunakan untuk meningkatkan imunitas tubuh seperti kunyit, temulawak dan kunci yang ada disekitar desa terus dikembangkan dengan budidaya secara masal yaitu pemanfaatan lahan perengan atau lahan disekitar rumah. Pemanfaatan ini akan memberikan nilai tambah ekonomi, kesehatan dan pelestarian lingkungan hidup yang berwawasan lingkungan.

Tabel 2. Persepsi Masyarakat Desa Torongrejo pada Budidaya Tanaman Rempah dan Pemanfaatannya

\begin{tabular}{lcc}
\hline \multicolumn{1}{c}{ Pernyataan } & $\mathbf{\%}$ & Interpretasi \\
\hline Tingkat budidaya tanaman rempah & 50 & Tidak \\
Budidaya tanaman rempah meliputi temulawak, kunci, kunyit & 38 & Tidak \\
Pemanfaatan tanaman sebagai bumbu masakan dan jamu & 88 & Iya \\
Tingkat konsumsi jamu masyarakat & 77 & Iya \\
\hline
\end{tabular}


Persepsi masyarakat terhadap budidaya tanaman rempah memberikan respon $50 \%$ tidak setuju. Hal ini disebabkan berdasar topografi bahwa daerah terongrejo mempunyai ketinggian diatas $1250 \mathrm{mdpl}$. Lahan yang berada pada ketinggian tersebut sangat cocok untuk budidaya hortikultura. Hasil panen lebih cepat lebih cepat dengan interval waktu panen 1 - 3 bulan. Adapun budidaya tanaman empon empon membutuhkan waktu panen 1 tahun sehingga petani kurang setuju. Keadaan ini terkait dengan kebutuhan hidup sehari hari yang relatif bisa di topang dari hasil tanam sayur sayuran.

Budidaya tanaman temulawak, kunyit dan kunci respon dari masyarakat adalah 38\% tidak setuju. Hal ini menunjukkan bahwa masyarakat juga mempunyai kebutuhan terhadap hasil tanaman empon empon meskipun harus ditanam disekitar rumah atau lahan perengan atau lahan kosong agar tidak mempengaruhi sumber pendapatan utama.

Tanggapan masyarakat terhadap pemanfaatan tanaman rempah sebagai bahan masak dan jamu menunjukkan 88 \%. Hal ini memperlihatkan bahwa didalam kehidupan sehari hari tanaman rempah sangat diperlukan oleh masyarakat, baik muntuk bumbu masak atau untuk jamu tradisional.

Masyarakat dalam kehidupan yang jauh dari apotik sangat mendambakan bahwa tubuhnya harus sehat. Adapun alternatif yang bisa dilakukan adalah dengan mengkonsumsi jamu herbal yang bisa dibuat sendiri dan bahan baku tersedia disekitar rumah. Respon masyarakat menunjukkan $77 \%$ sering mengkonsumsi jamu herbal atau tradisional yang dibuat sendiri. Khasiat kurkuminoid dalam pengobatan terutama sebagai antihepatoksik dan antikolesterol, serta obat tumor dan kanker. Komponen fenolik dalam kunyit dapat menghambat pertumbuhan kanker dan mempunyai aktivitas antimutagenik, kunyit juga dapat menekan pertumbuhan kanker usus, payudara, paru-paru, dan kulit (Sari, 2016).

\section{KESIMPULAN}

Pemanfaatan tanaman rempah empu Kunyit, empu Temulawak dan empu Kunci sebagai jamu instan dapat meningkatkan daya imunitas tubuh untuk mencegah terpapar Covid-19_delta. Program ini bisa dikata berhasil dimana masyarakat bersedia membuat dan mengkonsumsi jamu tradisioanal yang terbiat dari anaman rempah empu kunyit, empu temulawak dan empu kunci untuk meningkatkan imunutas tubuh agar terhindar dari terjangkit virus Covid-19.

\section{UCPAN TERIMA KASIH}

Ucapan terima kasih disampaikan kepada Lembaga Penelitian dan Pengabdian kepada Masyarakat (LPPM), Universitas Islam Malang, yang telah memberikan kesempatan untuk dapat melakukan program pengabdian kepada masyarakat ini. Kepada kelompok tani dan segenap jajaran Pemerintah Desa Torongrejo, Kecamatan Junrejo, Kota Batu yang telah memberikan sambutan baik terhadap pelaksanaan berbagai kegiatan yang dilakukan.

\section{DAFTAR RUJUKAN}

Bermawie, N. (2020). Potensi Tanaman Rempah Obat dan Atsiri Meghadapi Pandemi Covid 19. Pusat Penelitian dan Pengembangan Perkebunan, Balai Penelitian Tanaman Rempah dan Obat. https://balittro.litbang.pertanian.go.id/wpcontent/uploads/2017/03/Edisi-Khusus-2021-1.pdf

Dewi, R. S. (2019). Persepsi Masyarakat Mengenai Obat Tradisional di Kelurahan Simpang Baru Kecamatan Tampan Kota Pekanbaru. Jurnal Penelitian Farmasi Indonesia, 8(2), 75-79. https://doi.org/10.51887/jpfi.v8i2.782

Dhiani, B. A., Nurjanah, S., Putri, N. I., \& Umam, I. I. (2021). Peningkatan pengetahuan guru dan orang tua siswa taman kanak-kanak tentang penggunaan suplemen vitamin yang 
tepat. Jurnal Inovasi Hasil Pengabdian Masyarakat (JIPEMAS), 4(2), 161-168. https://doi.org/10.33474/jipemas.v4i2.9138

Firdaus, S. (2021). Data Lengkap Kasus Covid-19 di Indonesia per 12 Agustus 2021. IDN Times. https://www.idntimes.com/news/indonesia/sandy-firdaus/data-lengkapkasus-covid-19-di-indonesia-per-12-agustus $/ 1$

Kusumo, A. R., Wiyoga, F. Y., Perdana, H. P., Khairunnisa, I., Suhandi, R. I., \& Prastika, S. S. (2020). Jamu Tradisional Indonesia: Tingkatkan Imunitas Tubuh Secara Alami Selama Pandemi. Jurnal Layanan Masyarakat (Journal of Public Services), 4(2), 465. https://doi.org/10.20473/jlm.v4i2.2020.465-471

Martino, Y. A., Sulistiowati, E., \& Purnomo, Y. (2018). Model Pemberdayaan Santri Ponpes AlHidayah Batu Alang Sebagai Kader Kesehatan Berbasis Terapi Herbal. Jurnal Inovasi Hasil Pengabdian Masyarakat (JIPEMAS), 1(2), 86-93. https://doi.org/10.33474/jipemas.v1i2.1514

Pramesthi, D., Ardyati, I., \& Slamet, A. (2020). Potensi Tumbuhan Rempah dan Bumbu yang Digunakan dalam Masakan Lokal Buton sebagai Sumber Belajar. Biodik, 6(3), 225232. https://doi.org/10.22437/bio.v6i3.9861

Sari, A. N. (2016). Berbagai tanaman rempah sebagai sumber antioksidan alami. Elkawnie: Journal of Islamic Science and Technology, 2(2), 203-212. https://doi.org/10.22373/ekw.v2i2.2695

Satgas Covid Torongrejo. (2021). Data Covid-19 Desa Torongrejo. Pemdes Torongrejo.

Utami, P., \& Puspaningtyas, D. E. (2013). The Miracle of Herbs (Y. Indah (ed.)). PT. AgroMedia Pustaka. 